\title{
Biological activities of cell envelope fragments of the archaeobacterium Sulfolobus solfataricus: lethal toxicity, local hypersensitivity, pyrogenicity and spleen lymphocyte mitogenicity
}

\author{
Francesco Galdiero, ${ }^{1 *}$ Linda Sommese, ${ }^{1}$ Antonella Marcatili, ${ }^{1}$ Pasquale Scarfogliero, ${ }^{1}$ \\ Ciro Capasso, ${ }^{1}$ Alessandra Morana ${ }^{2}$ and Massimiliano Galdiero ${ }^{1}$ \\ ${ }^{\mathrm{t} I s t i t u t o}$ di Microbiologia, Facoltà di Medicina e Chirurgia, Seconda Università degli Studi di Napoli, Larghetto \\ S. Aniello a Caponapoli, 2, I-80138 Napoli, Italy \\ ${ }^{2}$ Istituto di Biochimica delle Macromolecole, Facoltà di Medicina e Chirurgia, Seconda Università degli Studi di \\ Napoli, Via Costantinopoli, 16, I-80138 Napoli, Italy
}

(Received 14 October 1992; revised 2 April 1993; accepted 27 April 1993)

\begin{abstract}
The sensitizing effect and the local and general toxicity related to membrane components of the archaeobacterium Sulfolobus solfataricus was studied. Cell envelope fragments were biologically active but this activity was lost upon separation of the lipid and protein components. The envelope fragments exerted lethal effects on mice sensitized with D-galactosamine that were prevented by pretreatment with anti-TNF- $\alpha$ serum. This lethal activity occurred in both LPS-responder (BALB/cByJ) and LPS-nonresponder (C3H/HeJ) mouse strains. In addition, Sulfolobus envelope fragments tested in rabbits caused a local Shwartzman reaction, and showed pyrogenic activity. In vitro, the envelope fragments that act on spleen lymphocytes of the LPS-responder (BALB/cByJ) and LPSnonresponder $(\mathrm{C} 3 \mathrm{H} / \mathrm{HeJ})$ mice caused an uptake of $\left[{ }^{3} \mathrm{H}\right]$ thymidine similar to that caused by concanavalin $\mathrm{A}$. A similar toxic activity to that exerted by eubacteria is therefore exerted by this non-pathogenic archaeobacterium despite the difference in surface chemistry.
\end{abstract}

\section{Introduction}

Septic shock is mediated by both Gram-positive and Gram-negative micro-organisms, often manifested by similar clinical symptoms (Wardle, 1979). Bacterial endotoxin, with its two components, lipopolysaccharide (LPS) and protein (Galdiero et al., 1984, 1990; Mangan et al., 1992; Sultzer et al., 1986), is the main Gramnegative pathogenic factor. Gram-positive bacteria lack endotoxins, but their surface components are believed to induce toxic shock through the same pathway as endotoxin (Wardle, 1979). Macrophages are the target cells of endotoxin (Freudenberg et al., 1986) and TNF- $\alpha$ is the main mediator of LPS toxicity (Beutler et al., 1985; Freudenberg \& Galanos, 1991). It is noteworthy that substances as chemically different as LPS and Grampositive surface components are all active, probably through different mechanisms, via the same terminal pathway.

The lethal activity of endotoxin may be enhanced both

*Author for correspondence. Tel. 0815665663 ; fax 0815665664 .

Abbreviations: Con A, concanavalin A; SE, Sulfolobus envelope; TNF, tumour necrosis factor. with micro-organisms (Salmonella typhimurium and Coxiella burnetii) and with hepatotoxic agents such as lead acetate (Selye et al., 1966), $\alpha$-amanitin (Seyberth $e t$ al., 1972) and D-galactosamine (Galanos et al., 1979). Infection by Gram-negative and Gram-positive bacteria, such as Mycobacterium bovis (BCG) and Propionibacterium acnes, enhances the endotoxin sensitivity of test animals.

There is a clear evolutionary distinction between eubacteria and archaeobacteria, particularly in the molecular structure of their cell wall components. The membrane lipids of archaeobacteria differ totally in structure and molecular architecture from those found in other living organisms (De Rosa \& Gambacorta, 1988). Sulfolobus solfataricus is a facultative sulphur-oxidizing autotroph whose natural habitat is hot acidic springs (pH 1, $\left.89^{\circ} \mathrm{C}\right)$ (Brock, 1978). Like other archaeobacteria, $S$. solfataricus has a simple cell wall consisting essentially of the S-layer attached to the plasma membrane (Weiss, 1974). The S-layer is composed of protein subunits in a hexagonal array, the dominating protein being a glucosamine-containing glycoprotein (Taylor et al., 1982).

Given this diversity in stimuli leading to the same 
symptomology, we investigated whether endotoxin-like activity is also exerted by surface structures of the archaeobacterium $S$. solfataricus.

\section{Methods}

Animals. For toxicity tests 10-20-week-old mice (LPS-responder strain BALB/CByJ and LPS-nonresponder strain $\mathrm{C} 3 \mathrm{H} / \mathrm{HeJ}$ of both sexes) were used. Six-week-old mice (LPS-responder strain BALB/cByJ and LPS-nonresponder $\mathrm{C} 3 \mathrm{H} / \mathrm{HeJ}$ of both sexes) served as donors of spleen lymphocytes. New Zealand White rabbits of both sexes weighing $2-3 \mathrm{~kg}$ were used to test for pyrogenicity and the Shwartzman reaction.

Bacteria. Sulfolobus solfataricus strain DSM 1617 was used. Cultures were grown at $88{ }^{\circ} \mathrm{C}, \mathrm{pH} 3.5$, in basal salts medium with $0.1 \%$ yeast extract (Brock et al., 1972). Cultures were grown to the early exponential phase $\left(10^{7}-10^{8}\right.$ bacteria $\left.\mathrm{ml}^{-1}\right)$ harvested by centrifugation for $15 \mathrm{~min}$ at $8000 \mathrm{~g}$ and washed three times with $0.15 \mathrm{M}$ cold phosphate-buffered saline (PBS) pH 7.2 (per litre: $8 \mathrm{~g} \mathrm{NaCl}, 0.2 \mathrm{~g} \mathrm{KCl}$, $1 \cdot 15 \mathrm{~g} \mathrm{Na}_{2} \mathrm{HPO}_{4}, 0.2 \mathrm{~g} \mathrm{KH}_{2} \mathrm{PO}_{4}$ ) according to Weiss (1974) with some modifications. Briefly, a concentrated cell suspension in PBS containing DNAase and RNAase was passed through a French press at a pressure just sufficient to obtain cell breakage $(41.37 \mathrm{kPa})$.

The intact cells were separated by centrifugation at $600 \mathrm{~g}$ for $10 \mathrm{~min}$. Supernatant consisting of cell envelope fragments (Sulfolobus envelope, SE fragments) was collected, dialysed and lyophilized.

Processing of SE fragments. SE fragment suspensions were sonicated with an ultrasonic homogenizer (Labsonic U, Braun) at $60 \mathrm{~W}$ for two periods of $1 \mathrm{~min}$ each; the suspensions were cooled between each cycle. The suspensions were examined by electron microscopy (EM 109, Zeiss), then analysed by SDS-PAGE according to Laemmli (1970). Gels were stained with Coomassie blue and silver nitrate as described by Tsai \& Frasch (1982).

To separate the lipid components, the dried SE fragments were extracted at room temperature for $24 \mathrm{~h}$ with $3 \mathrm{ml} \mathrm{CHCl}_{3} / \mathrm{CH}_{3} \mathrm{OH}(1: 1$, $\mathrm{v} / \mathrm{v})$. The insoluble protein material was separated from the lipid extract by centrifugation, the solvent removed by nitrogen flow, and the extracted fraction analysed by thin-layer chromatography on silica gel $\mathrm{G}$ plates (Merck, D) in $\mathrm{CHCl}_{3} / \mathrm{CH}_{3} \mathrm{OH} / \mathrm{H}_{2} \mathrm{O}$ (65:25:15, by vol.). The extracted fraction consisted of lipid components already identified in S. solifataricus (Nicolaus et al., 1990). The insoluble fraction, suspended in PBS, was analysed by electrophoresis. These two components were tested for biological activity (lethal toxicity, local hypersensitivity, pyrogenicity and spleen lymphocyte mitogenicity) using as control SE fragments that had been treated with $1.5 \mathrm{ml}$ $\mathrm{CHCl}_{3} / \mathrm{CH}_{3} \mathrm{OH}(1: 1, \mathrm{v} / \mathrm{v})$ for $24 \mathrm{~h}$ after which the solvent was removed by nitrogen flow. For injection, the protein fractions were suspended in pyrogen-free PBS; the lipid fractions were dissolved in an emulsion of soyabean oil, egg lecithin and glycerol as described by Coran (1972). The lipid plus protein fractions were reconstituted by incorporating them in liposomes constituted by $\mathrm{L}-\alpha$-phosphatidylcholine $(63 \mu \mathrm{mol})$, dicetyl phosphate $(18 \mu \mathrm{mol})$ and cholesterol $(9 \mu \mathrm{mol})$ prepared according to Wassef \& Alving (1987). Other differently composed liposomes (Galdiero et al., 1991) gave similar results.

Analytical methods. The protein content was measured by the Lowry method using bovine serum albumin as a standard. Quantitative analysis of neutral sugar was done by the phenol/sulphuric acid method (Dubois et al., 1956) in which phenol is the specific organic colour developing agent. The sulphophosphovanillin reaction (Boehringer Mannheim) was used to determine total lipids. LPS-free labware and solutions were used throughout this study.

The Limulus amoebocyte lysate (LAL) assay (Microbiological Associates) was used to examine preparations for traces of LPS contamination using as controls endotoxin-free water (lot no. 2243/3, Bieffe) and Westphal-extracted Escherichia coli O111; B4 LPS (Difco) (Thye Yin et al., 1972). Inhibition of LAL was examined by serial dilutions and LPS recovery according to Munson (1985).

Toxicity test in mice. Lethal toxicity tests were carried out in D-galactosamine-sensitized LPS-responder and -nonresponder mice according to Galanos et al. (1979). LPS of E. coli O128:B12 (Difco) ( $50 \mu \mathrm{g}$ per mouse) or SE fragments (1 mg per mouse) were injected intravenously into the lateral tail vein as a mixture with Dgalactosamine hydrochloride (20 mg per mouse) (Sigma) in $0.2 \mathrm{ml}$ pyrogen-free PBS. Controls received D-galactosamine, LPS or SE fragments in $0.2 \mathrm{ml}$ pyrogen-free PBS. Deaths were recorded up to $24 \mathrm{~h}$ after injection.

Anti-TNF- $\alpha$ serum inhibition of lethal toxicity induced by SE fragments. LPS-responder mice were injected intravenously with $100 \mu \mathrm{l}$ rabbit anti-murine TNF- $\alpha$ serum (Genzyme) according to Freudenberg \& Galanos (1991). After $10 \mathrm{~min}$ the animals were challenged with lethal amounts of LPS ( $50 \mu \mathrm{g}$ per mouse) or SE fragments ( $1 \mathrm{mg}$ per mouse) administered intravenously together with $\mathrm{D}$-galactosamine $(20 \mathrm{mg}$ per mouse) in $0.2 \mathrm{ml}$ pyrogen-free PBS.

Local Shwartzman reaction in rabbits. New Zealand White rabbits $(2-3 \mathrm{~kg})$ were each injected intradermally on their shaved abdomen with $100 \mu \mathrm{g}$ LPS in $0.5 \mathrm{ml}$ pyrogen-free physiological saline. After $20 \mathrm{~h}$ they were each injected intravenously with $300 \mu \mathrm{g}$ LPS in $0.5 \mathrm{ml}$ pyrogen-free physiological saline in the right marginal ear vein. Another group of rabbits was injected intradermally with SE fragments (1 mg in $0.5 \mathrm{ml}$ pyrogen-free physiological saline per rabbit). Then $20 \mathrm{~h}$ later they were each injected intravenously with $3 \mathrm{mg}$ SE fragments in $0.5 \mathrm{ml}$ pyrogen-free physiological saline. Control rabbits were injected intradermally with $0.5 \mathrm{ml}$ physiological saline, and $20 \mathrm{~h}$ later they were injected with a provoking dose of LPS ( $300 \mu \mathrm{g}$ per rabbit). All three groups were monitored for $24 \mathrm{~h}$ after LPS challenge for the appearance of haemorrhagic necrosis, which signalled a positive response.

Pyrogenicity in rabbits. Pyrogenicity was determined in New Zealand White rabbits by intravenously injecting each one with LPS $(10 \mu \mathrm{g}$ in $0.5 \mathrm{ml}$ pyrogen-free physiological saline) or SE fragments $(200 \mu \mathrm{g}$ in $0.5 \mathrm{ml}$ pyrogen-free physiological saline) and monitoring rectal temperature changes according to the European Pharmacopoeia (1971). Control rabbits were injected intravenously with $0.5 \mathrm{ml}$ pyrogen-free physiological saline.

SE-fragment-induced mitogenicity of spleen lymphocytes. Cells were prepared from mouse spleens that had been aseptically removed, minced and washed three times in RPMI 1640 (Labtek). Then 0.17 M$\mathrm{NH}_{4} \mathrm{Cl}$ was added to lyse the red blood cells and, after two washings with RPMI 1640, the lymphocytes were isolated on Milieu de separation des lymphocytes (Eurobio) at $600 \mathrm{~g}$ for $30 \mathrm{~min}$ at room temperature. The isolated lymphocytes were washed and resuspended in RPMI 1640. Cell viability was evaluated with the trypan blue exclusion test. Spleen cells were resuspended in RPMI 1640 at a concentration of $3 \times 10^{6} \mathrm{cells} \mathrm{m}^{-1}$. Aliquots of $100 \mu \mathrm{l}$ placed in multiwell plates with concanavalin A (Con A, Miles-Yeda) $(1.2 \mu \mathrm{g})$, LPS $(2 \mu \mathrm{g})$ or SE fragments $(50-200 \mu \mathrm{g})$ per well were incubated in $5 \%$ (v/v) $\mathrm{CO}_{2}$ at $37^{\circ} \mathrm{C}$ for $72 \mathrm{~h}$. Six hours before termination of culture $\left[{ }^{3} \mathrm{H}\right]$ thymidine $[0.5 \mu \mathrm{Ci}(18.5 \mathrm{kBq})$, specific activity $5 \mathrm{Ci}(185 \mathrm{GBq})$ $\mathrm{mmol}^{-1}$ ] (Amersham) was added to each culture. All cultures were harvested with a multiple automated sample harvester (Skatron Cell Harvester, Biotech) onto glass-fibre filters. The filters were dried and placed in vials filled with $3 \mathrm{ml}$ scintillation cocktail (Ready Gel, Beckman) and counted in a Beckman gamma counter with a standard error of $0.5 \%$. Untreated and unstimulated murine lymphocytes were used as controls. 
Statistics. All experiments were performed in triplicate; results were expressed as the mean \pm SD. Comparisons between tests were done by Student's $t$ test with statistical significance at $P<0.05$.

\section{Results}

Analysis of SE fragments

In the procedure used to isolate cell wall fragments, intact cells were initially disrupted by passing washed bacteria through a French press. Chemical analysis of our preparation showed a protein/carbohydrate/lipid ratio of $1: 0 \cdot 12: 0 \cdot 008$ (by wt). PAGE showed several protein bands that were stained by Coomassie blue (Fig. 1) and only one band stained by silver nitrate (Fig. 2). Only the intact SE fragments showed biological activity, the lipid or protein components showing none (Table 1).

\section{Lethal activity of SE fragments in D-galactosamine- treated mice}

Table 1 summarizes the results obtained with LPSresponder and -nonresponder mice. As expected, purified LPS was highly toxic in D-galactosamine-treated LPS-

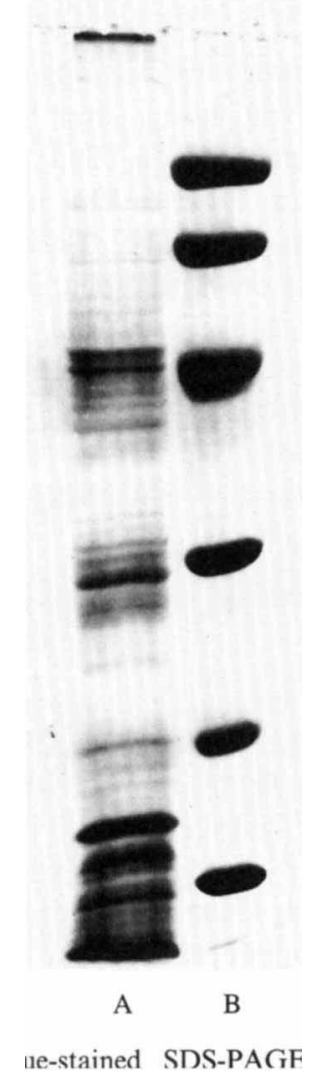

Fig. 1. Coomassie-blue-stained SDS-PAGE pattern of envelope proteins of $S$. solfataricus. Lane A, S. solfataricus envelope proteins. Lane B, molecular mass standards (phosphorylase $b, 94 \mathrm{kDa}$; albumin, $67 \mathrm{kDa}$; ovalbumin, $43 \mathrm{kDa}$; carbonic anhydrase, $30 \mathrm{kDa}$; soybean trypsin inhibitor, $20 \cdot 1 \mathrm{kDa} ; \alpha$-lactalbumin, $14.4 \mathrm{kDa}$.

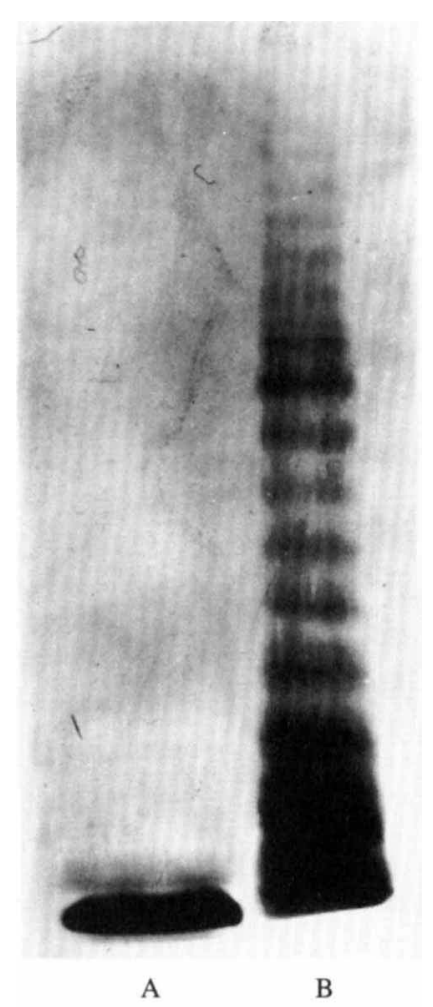

Fig. 2. Silver-stained polyacrylamide gel $(15 \%, w / v$, acrylamide $)$ of $S$. solfataricus. Lane A, S. solfataricus band; lane B, smooth LPS from Salmonella typhimurium (Difco).

responder mice. It caused $90 \pm 5 \%$ mortality at a dose of $50 \mu \mathrm{g}$ in $0.2 \mathrm{ml}$ pyrogen-free PBS. The same dose had no lethal effect in LPS-nonresponder mice. SE fragments ( $1 \mathrm{mg}$ in $0.2 \mathrm{ml}$ pyrogen-free PBS) caused about $80 \pm 5 \%$ mortality in both D-galactosamine-treated LPSresponder and -nonresponder mouse strains. LPS or SE fragments, at the same doses as above, injected into control animals not treated with D-galactosamine, did not cause any mortality. Lethal activity in Dgalactosamine-treated mice started at an SE fragment dose of $0.5 \mathrm{mg}$ and reached a peak at $1 \mathrm{mg}$ (Table 1 ).

\section{Inhibition of the toxicity by anti-TNF- $\alpha$ serum}

To show that the lethal effect induced by the administration of SE fragments was mediated by TNF- $\alpha$ as reported for LPS (Freudenberg \& Galanos, 1991), mice treated with anti-TNF- $\alpha$ serum were challenged with SE fragments or LPS. Table 2 shows the results obtained after treating the mice with $100 \mu$ l anti-murine TNF- $\alpha$ serum. Anti-TNF- $\alpha$ serum inhibited the lethal activity induced by SE fragments ( $1 \mathrm{mg}$ in $0.2 \mathrm{ml}$ pyrogen-free PBS), as well as that induced by LPS. All treated animals survived. Control D-galactosamine-treated mice, injected with $100 \mu \mathrm{l}$ of a normal rabbit serum before lethal challenge with LPS or SE fragments, were not protected. 
Table 1. Lethal toxicity of SE fragments of

$S$. solfataricus in D-galactosamine-treated mice

Groups of 10 mice each received intravenously the agent tested and D-galactosamine as a mixture in $0.2 \mathrm{ml}$ of pyrogen-free PBS. The results are means of three experiments + SD. LPS-responder and -nonresponder mice treated with $S E$ lipid fractions, SE protein fractions, or SE reconstituted lipid + protein fractions showed no mortality.

\begin{tabular}{ccc}
\hline \hline & \multicolumn{2}{c}{ Mortality (\%) } \\
\cline { 2 - 3 } Agent & $\begin{array}{c}\text { LPS-responder } \\
\text { mice } \\
(\text { BALB/cBy })\end{array}$ & $\begin{array}{c}\text { LPS-nonresponder } \\
\text { mice } \\
(\mathrm{C} 3 \mathrm{H} / \mathrm{HeJ})\end{array}$ \\
\hline Control & 0 & 0 \\
LPS from E. coli & & \\
O128:B12 & & \\
$(50 \mu \mathrm{\mu g})$ & $90 \pm 5$ & 0 \\
SE fragments of & & \\
S. solfataricus & & \\
$(2 \mathrm{mg})$ & $85 \pm 5$ & $80 \pm 5$ \\
$(1 \mathrm{mg})$ & $85 \pm 5$ & 0 \\
$(0 \cdot 5 \mathrm{mg})$ & $10 \pm 3$ & 0 \\
$(0 \cdot 1 \mathrm{mg})$ & 0 & \\
\hline \hline
\end{tabular}

Table 2. Inhibition of $S E$ fragment-induced mortality by anti-TNF- $\alpha$ serum in $B A L B / c B y J$ mice

Groups of 10 mice each received intravenously the anti-TNF- $\alpha$ serum $(100 \mu \mathrm{l})$ and, after $10 \mathrm{~min}$, a mixture of the agent being tested and D-galactosamine in $0.2 \mathrm{ml}$ pyrogen-free PBS. All controls survived. The results are means of three independent experiments $\pm \mathrm{SD}$

\begin{tabular}{|c|c|}
\hline Challenge & $\begin{array}{c}\text { Mortality } \\
(\%)\end{array}$ \\
\hline $\begin{array}{l}\text { LPS from } E \text {. coli } \mathrm{O} 128: \mathrm{B} 12 \\
(50 \mu \mathrm{g})+\text { anti-TNF- } \alpha \text { serum } \\
(100 \mu)\end{array}$ & 0 \\
\hline $\begin{array}{l}\text { LPS from E. coli O128:B12 } \\
(50 \mu \mathrm{g})+\text { normal rabbit serum } \\
(100 \mu \mathrm{l})\end{array}$ & $90 \pm 5$ \\
\hline $\begin{array}{l}\text { SE fragments of } S \text {. solfataricus } \\
(1 \mathrm{mg})+\text { anti-TNF- } \alpha \text { serum } \\
(100 \mu \mathrm{l})\end{array}$ & 0 \\
\hline $\begin{array}{l}\text { SE fragments of } S \text {. solfataricus } \\
(1 \mathrm{mg})+\text { normal rabbit serum } \\
(100 \mu \mathrm{l})\end{array}$ & $85 \pm 5$ \\
\hline
\end{tabular}

Local Shwartzman reaction in rabbits treated with $S E$ fragments

As expected, rabbits pretreated with a sensitizing dose of LPS (100 $\mu \mathrm{g}$ per rabbit) showed a positive haemorrhagic necrosis within $24 \mathrm{~h}$ of an intravenous injection of an LPS challenge dose ( $300 \mu \mathrm{g}$ per rabbit). The width of the necrotic area in these rabbits was $3 \pm 1 \mathrm{~cm}$.

Rabbits pretreated with a sensitizing dose of SE fragments (1 mg per rabbit) showed positive haemorrhagic necrosis after receiving a challenge injection
Table 3. $\left[{ }^{3} H\right]$ Thymidine incorporation in splenocytes stimulated in vitro with LPS of E. coli O128:B12, Con $A$ and $S E$ fragments

The results are means of three experiments \pm SD.

\begin{tabular}{|c|c|c|c|}
\hline \multirow[b]{2}{*}{ Agent* } & & \multicolumn{2}{|c|}{$\left[{ }^{3} \mathrm{H}\right] \mathrm{T}$ hymidine incorporation (c.p.m.) } \\
\hline & & $\begin{array}{c}\text { LPS-responder } \\
\text { mice } \\
(\mathrm{BALB} / \mathrm{cBy} \mathrm{J})\end{array}$ & $\begin{array}{c}\text { LPS-nonresponder } \\
\text { mice } \\
(\mathrm{C} 3 \mathrm{H} / \mathrm{HeJ})\end{array}$ \\
\hline None & & $290 \pm 20$ & $270+20$ \\
\hline LPS & $(2 \mu \mathrm{g})$ & $1990+150$ & $450+20$ \\
\hline Con A & $(1 \cdot 2 \mu \mathrm{g})$ & $14310+250$ & $3910+60$ \\
\hline \multirow[t]{3}{*}{ SE fragments } & $(50 \mu \mathrm{g})$ & $4150 \pm 100$ & $5720 \pm 80$ \\
\hline & $(100 \mu \mathrm{g})$ & $12550 \pm 220$ & $14420 \pm 240$ \\
\hline & $(200 \mu \mathrm{g})$ & $6790 \pm 100$ & $8330 \pm 100$ \\
\hline
\end{tabular}

*Amount per well $(100 \mu l$ volume) shown in parentheses.

(3 mg per rabbit) of SE fragments. The width of the necrotic zone was $3.4 \pm 1 \mathrm{~cm}$. Control rabbits injected intradermally with $0.5 \mathrm{ml}$ pyrogen-free physiological saline (sensitizing injection) and then injected with a challenge dose of LPS or SE fragments did not show any necrotic zone.

\section{Pyrogenicity in rabbits treated with SE fragments}

The rectal temperature of rabbits treated with LPS $\left(10 \mu \mathrm{g}\right.$ per rabbit) increased after $30 \mathrm{~min}\left(1^{\circ} \mathrm{C}\right)$ with respect to basal temperature. This increase reached a peak (about $+3{ }^{\circ} \mathrm{C}$ ) $120 \mathrm{~min}$ after injection. The rectal temperature slowly returned towards basal values 360 min after injection. Rabbits treated with SE fragments $(200 \mu \mathrm{g}$ per rabbit) showed similar rectal temperature increases. At $60 \mathrm{~min}$ after injection, rectal temperature was about $1{ }^{\circ} \mathrm{C}$ above the basal temperature; it peaked (about $+3^{\circ} \mathrm{C}$ ) at $90 \mathrm{~min}$, and returned towards basal values after $360 \mathrm{~min}$.

\section{Spleen lymphocyte mitogenicity induced by $S E$ fragments}

The stimulatory effect of SE fragments were compared with those of E. coli O128:B12 LPS and Con A. The results presented in Table 3 show that, in the responding strain of mice, the stimulatory activity of SE fragments $(100 \mu \mathrm{g})$ was similar to that induced by Con $\mathrm{A}$. In the nonresponder group, the blastogenic activity of SE fragments was even greater than that induced by Con A.

\section{Discussion}

The toxicity of surface components of Gram-positive and Gram-negative bacteria is a well known phenom. enon, LPS being the most toxic (Freudenberg \& Galanos, 
1991). Our results demonstrate that a similar toxic activity is exerted by surface components (SE fragments) extracted from archaeobacteria, which are chemically different from eubacteria. As these bacteria are present in the environment they have the potential to interact with humans and animals.

SE fragments had a lethal effect in D-galactosaminesensitized mice. They induced a local Shwartzman reaction, had pyrogenic activity, and stimulated spleen lymphocytes to proliferate. The possibility that these effects were due to the presence of LPS contaminants in our SE preparations was ruled out by the Limulus test. In addition, LPS-nonresponder $(\mathrm{C} 3 \mathrm{H} / \mathrm{HeJ})$ mice were not affected by LPS, but after SE injection the mortality almost reached that of LPS-responder (BALB/cByJ) mice. This suggested that if there were traces of LPS in our SE preparations, they must have been below $1 \mathrm{ng}$ (Galanos et al., 1979). Mouse strains are nonresponsive to most of the biological effects of lipid A (Rosenstreich, 1985 ) a lipid that is not found in S. solfataricus (De Rosa $\&$ Gambacorta, 1988). Because the identity and the concentration of toxic components in the $S$. solfataricus cells have yet to be established, comparison with LPS cannot be made.

The SE preparation we used for this study is active at a relatively high concentration. The molecular configuration of the active molecule is probably hidden within the fragment, and the loss of the appropriate protein molecular configuration, after separation of the hydrophobic and hydrophilic components, results in loss of activity. Reconstitution of the lipid and protein fractions in liposomes does not result in the appearance of the native configuration and hence activity is lost.

The use of D-galactosamine-treated mice for mortality tests was originally designed to measure the toxicity of very low amounts of LPS (Galanos et al., 1979). DGalactosamine does not increase sensitivity of mice to LPS, but rather to the lethal action of endogenous mediators, particularly TNF- $\alpha$ (Freudenberg \& Galanos, 1988; Lehmann et al., 1987). This implies that Dgalactosamine-treated animals would be highly sensitive to the lethal action of any agent capable of inducing TNF- $\alpha$ secretion. In our experiments the toxic effect exerted by SE fragments was completely suppressed by injecting mice with anti-TNF- $\alpha$ serum (Freudenberg \& Galanos, 1991).

Our S. solfataricus preparations showed local hypersensitivity and pyrogenic activity, which is mediated both by the cells themselves and by the cytokines, similar to those caused by LPS. Thus, chemically different substances act through a final common pathway that induces the secretion of different types of endogenous mediators, which in turn produce a different response according to the specific target cell involved and to the type of cytokine released. Many surface components of Grampositive bacteria cause the release of cytokines including TNF- $\alpha$ (Tuomanen et al., 1987; Oppenheim et al., 1980; Iribe et al., 1981). Lipoteichoic acid from Streptococcus pyrogenes administered to mice primed with $P$. acnes induced TNF release in serum (Yamamoto et al., 1985). A blastogenic response, similar to that produced by Con A stimulation, is also induced by SE fragments to the same extent in both LPS-responder and -nonresponder mouse spleen cells. The need for more than one cell type and more than one cytokine in the amplification of cell proliferation in nonresponder mice could account for the weaker reaction to Con A. Both LPS-responder and -nonresponder mice are sensitive to SE fragment stimulation.

The physiological parameters of $S$. solfataricus (optimal growth temperature $88^{\circ} \mathrm{C}$, minimum growth temperature $70^{\circ} \mathrm{C}$, optimal $\mathrm{pH} 3 \cdot 0$, maximum $\mathrm{pH} 5 \cdot 0$ ) prevent this bacterium from being even an occasional parasite of higher organisms. Therefore, it is clear that the effects (toxicity and hypersensitivity) induced by outer-envelope components of micro-organisms such as LPS are not the result of an evolutionary process following prolonged host-parasite interaction. Consequently, it can be postulated that the biological effects induced by the surface components of the archaeobacterium $S$. solfataricus depend on molecules very different from those of the vast majority of eubacteria. Our results indicate that careful chemical screening of the components of the archaeobacterial cell membrane could reveal substances that could be exploited as new immunomodulators.

\section{References}

Beutler, B., Milsex, I. W. \& Cerunt, A. (1985). Passive immunization against cachectin/tumor necrosis factor (TNF) protects mice from the lethal effect of endotoxin. Science 229, 869-871.

Brock, T. D. (1978). Thermophilic Microorganisms and Life at High Temperatures, pp. 117-179. New York: Springer.

Brock, T. D., Brock, K. M., Belly, R. T. \& Weiss, R. L. (1972). Sulfolobus: a new genus of sulfur-oxidizing bacteria living at low $\mathrm{pH}$ and high temperature. Archiv für Mikrobiologie 84, 54-68.

Coran, A. (1972). The intravenous use of fat for the total parenteral nutrition of the infant. Lipids 7, 455-457.

De Rosa, M. \& GambacorTA, A. (1988). The lipids of archaebacteria. Progress in Lipid Research 27, 153-175.

Dubois, M., Gilles, K. A., Hamilton, J. K., Rebers, P. A. \& Smith, F. (1956). Colorimetric method for determination of sugars and related substances. Analytical Chemistry 28, 350-356.

FreudenberG, M. A. \& Galanos, C. (1988). Induction of tolerance to (LPS)-D-galactosamine lethality by pretreatment with LPS is mediated by macrophages. Infection and Immunity 56, 1352-1357.

FreudenberG, M. A. \& Galanos, C. (1991). Tumor necrosis factor alpha mediated lethal activity of killed Gram-negative and Grampositive bacteria in D-galactosamine treated mice. Infection and Immunity 59, 2110-2115.

FreudenberG, M. A., KepPler, P. \& Galanos, C. (1986). Requirement for lipopolysaccharide responsive macrophages in galactosamineinduced sensitization to endotoxin. Infection and Immtunity 51, $891-895$. 
Galanos, C., Freudenberg, M. A. \& Reutter, W. (1979). Galactosamine induced sensitization to the lethal effects of endotoxin. Proceedings of the National Academy Sciences of the United States of America 76, 5939-5943.

Galdiero, F., Tufano, M. A., Sommese, L., Folgore, A. \& Tedesco, F. (1984). Activation of complement system by porins extracted from Salmonella typhimurium. Infection and Immunity 46, 559-563.

Galdiero, F., Tufano, M. A., Galdiero, M., Masiello, S. \& Di RosA, M. (1990). Inflammatory effects on Salmonella typhimurium porins. Infection and Immunity 58, 3183-3186.

Galdiero, F., Romano Carratelli, C., Bentivigi.io, C., Capasso, C., Cioffi, S., Folgore, A., Gorga, F., lanniello, R., Mattera, S., Nuzzo, I., Rizzo, A. \& Tufano, M. A. (1991). Correlation between modification of membrane phospholipids and some biological activity of lymphocytes, neutrophils and macrophages. Immunopharmacology and Immunotoxicology 13, 623-642.

Iribe, H, Koga, T., Onoue, K., Kotani, S., Kusumoto, S. \& Shiba, T. (1981). Macrophage-stimulating effect of a synthetic muramyldipeptide and its adjuvant-active and inactive analogs for the production of the cell-activating monokines. Cellular Immunology 64, 73-77.

LAEMMLI, U. K. (1970). Cleavage of structural proteins during the assembly of the head of bacteriophage T4. Nature, London 227, $680-685$.

Lehmann, V., Freudenberg, M. A. \& Galanos, C. (1987). Lethal toxicity of lipopolysaccharide and tumor necrosis factor in normal and D-galactosamine treated mice. Journal of Experimental Medicine 165, 657-663.

Mangan, D. F., Wahl, S. M., Sultzer, B. M. \& Mergenhagen, S. E. (1992). Stimulation of human monocytes by endotoxin-associated protein: inhibition of programmed cell death (apoptosis) and potential significance in adjuvanticity. Infection and Immunity $\mathbf{6 0}$, 1684-1686.

Munson, T. E. (1985). Structure, biomedical significance and detection with the Limulus Amebocyte Lysate test. In Bacterial Endotoxins, pp. 211-220. Edited by J. W. ten Cate, H. R. Buller \& A. Sturk. New York: Academic Press.

Nicolaus, B., Trincone, A., Esposito, E., Vaccaro, M. R., GambaCORTA, A. \& DE Rosa, M. (1990). Calditol tetraether lipids of the archaebacterium Sulfolobus solfataricus. Biochemical Journal 266, $785-791$.

Oppenheim, J. J., Togawa, A., Chedid, L. \& Mizel, S. (1980).
Components of mycobacteria and muramyl dipeptide with adjuvant activity induce lymphocyte activating factor. Cellular Immunology 50, 71-74.

ROSENSTREICH, D. L. (1985). Genetic control of endotoxin response: C3H/HeJ mice. In Handbook of Endotoxins, vol. 3, pp. 82-122. Edited by L. J. Berry. New York: Elsevier.

Selye, H., TuchWEBeR, B. \& Bertok, L. (1966). Effect of lead acetate on the susceptibility of rats to bacterial endotoxins. Journal of Bacteriology 91, 884-890.

Seyberth, H. W., Schmidt-Gay, K. H. \& Hackethal, E. (1972). Toxicity clearance and distribution of endotoxin in mice as influenced by actinomycin $\mathrm{D}$, cycloheximide, $\alpha$-amanitin and lead acetate. Toxicon 10, 491-500.

Sultzer, B. M., Craig, J. P. \& Castagna, R. (1986). Endotoxin associated proteins and their polyclonal and adjuvant activities. In Immunobiology and Immunopharmacology of Bacterial Endotoxins, pp. $435-447$. Edited by A. Szentivanyi \& H. Friedman. New York: Plenum.

Taylor, K. A., Deatherage, J. F. \& Amos, L. A. (1982). Structure of the S-layer of Sulfolobus acidocaldarius. Nature, London 299, $840-842$.

Thye Yin, E., Galanos, C., Kinsky, S., Bradshaw, R. A., Wessler, S., Luderity, O. \& Sarmiento, M. F. (1972). Picogram sensitive assay for endotoxin: gelation of Limulus polyphemus blood cell lysate induced by purified lipopolysaccharide and lipid A from Gramnegative bacteria. Biochimica et Biophysica Acta 261, 284-289.

Tsal, C. M. \& Frasch, C. E. (1982). A sensitive silver-stain for detecting lipopolysaccharides in polyacrylamide gels. Analytical Biochemistry 119, 115-119.

TuOmaneN, E., RiCH, R. \& ZAK, O. (1987). Induction of pulmonary inflammation by components of the pneumococcal cell surface. American Reviews of Respiratory Disease 135, 869-873.

WASSEF, N. M. \& Alving, C. R. (1987). Modulation of phosphatidylinositol turnover by liposomes containing phosphatidylinositol. Methods in Enzymology 141, 244-255.

WARDLE, E. N. (1979). Bacteraemic and endotoxic shock. British Journal of Hospital Medicine 21, 223-231.

WeISS, R. L. (1974). Subunit cell wall of Sulfolobus acidocaldarius. Journal of Bacteriology 118, 275-284.

Yamamoto, A., Usami, H., NagamuTa, M., Sugawara, Y., Hamada, S., Yamamoto, T., Kato, K., Kokeguki, S. \& Kotan], S. (1985). The use of lipoteichoic (LTA) from Streptococcus pyogenes to induce a serum factor causing tumor necrosis. British Journal of Cancer 51, $739-745$. 